\title{
PELATIHAN OLIMPIADE MATEMATIKA PADA GURU MATEMATIKA MADRASAH IBTIDAIYAH DI KKM-MI I KEDIRI KURIPAN LOMBOK BARAT
}

\author{
Mauliddin \\ Universitas Islam Negeri Mataram \\ Mauliddin1893@uinmataram.ac.id
}

\begin{abstract}
Abstrak: Pelatihan olimpiade matematika pada guru-guru matematika madrasah ibtidaiyah di KKM-MI I Kediri Kuripan Lombok Barat bertujuan untuk meningkatkan kemampuan guru-guru dalam melatih dan membina siswa-siswa di sekolahnya untuk dipersiapkan mengikuti kompetisi olimpiade matematika yang diselenggarakan oleh pemerintah setiap tahunnya yang tergabung dalam kompetisi OSN (Olimpiade Sains Nasional). Pelatihan olimpiade matematika diselenggarakan di Lombok Barat, bertempat di ruang rapat Institut Agama Islam Darul Hakim Kediri Lombok Barat, pada hari ahad tanggal 20 Agustus 2017. Kegiatan diawali dengan kegiatan pembukaan yang diisi oleh pengabdi dan ketua KKM-MI I Kediri Kuripan Lombok Barat. Selanjutnya materi dibawakan oleh dua orang narasumber dan peserta disuguhkan test sebanyak dua kali yakni pre test dan post test. Test tersebut bertujuan untuk mengetahui kemampuan awal dan akhir peserta sebagai bahan masukan saat pemberian materi serta bahan evaluasi keberhasilan pelatihan.
\end{abstract}

Kata Kunci: olimpiade matematika, OSN, pre-test, post-test

\begin{abstract}
Mathematics olympiad training for madrasah ibtidaiyah math teachers at KKM-MI I Kediri Kuripan West Lombok aims to improve the ability of teachers to train and nurture students in their schools to be prepared to take part in math olympiad competitions organized by the government every year, called OSN (National Science Olympiad) competition. The mathematics olympiad training was held at the meeting room of the Darul Hakim Kediri Islamic Institute in West Lombok, on the 20th of August 2017. The activity began with an opening activity filled by the team and heads of the KKM-MI I Kediri Kuripan, West Lombok. Then the material was delivered by two speakers and participants were presented with a twice test, namely pre-test and post-test. The test aims to determine the participants' initial and final abilities as input when giving material and materials to evaluate the success of the training.
\end{abstract}

Keywords: math olympiad, OSN, pre-test, post-test

\section{Pendahuluan}

Olimpiade Matematika merupakan kompetisi tahunan yang diselenggarakan secara resmi oleh pemerintah Republik Indonesia. Kompetisi ini merupakan ajang bergengsi untuk mempersiapkan putera-puteri terbaik bangsa untuk mewakili Indonesia di ajang Olimpiade Matematika Internasional. Momen ini pula dijadikan sebagai tolak ukur kualitas suatu sekolah dalam bidang matematika. Dimana sekolah diuji menjadi tim yang gemilang, yakni bukan sekedar kumpulan orang cerdas, namun dapat mendorong setiap orang untuk bekerja lebih giat, berpikir lebih matang, dan mencapai kesimpulan yang lebih baik, disamping mengandalkan kemampuan secara individual sebagaimana yang diungkapkan oleh James Surowiecki.

Persaingan siswa yang berasal dari berbagai sekolah di tanah air untuk memperebutkan juara dalam kompetisi Olimpiade Matematika dipandang cukup ketat. Sayangnya, siswa-siswa dari sekolah-sekolah dibawah kemenag tidak bermunculan sebagai sang juara, semua didominasi sekolah-sekolah dibawah kemendiknas. Rendahnya perhatian dan partisipasi 
sekolah, khususnya madrasah turut mendukung rendahnya kualitas siswa madrasah dalam kompetisi OSN. Padahal sebuah sekolah yang ingin maju harus memiliki perhatian yang baik terhadap peningkatan prestasi siswa-siswanya agar bisa unggul. Menurut Nanang Fattah , unggul berarti sekolah mampu menggunakan strategi peningkatan budaya mutu, strategi pengembangan kesempatan belajar, strategi memelihara kendali mutu, strategi penggunaan kekuasaaan maupun pengetahuan dan informasi yang diperoleh sekolah secara efisien.

Pemerintah melalui kemenag mengadakan KSM sebagai wadah bagi siswa-siswa madrasah untuk berkompetisi dalam regional agar mereka mampu bersaing dalam kompetisi OSN yang cakupannya lebih luas dan kompetitif agar terwujud bangsa yang cerdas, berbudi pekerti yang luhur serta terampil dan berpengetahuan. Sebagaimana tujuan pendidikan nasional yang terungkap dalam Umar Tirtarahardja (2005:271).

Adanya OSN dan KSM sebagai agenda rutin tahunan ,harusnya mampu memacu daya saing madrasah, utamanya madrasah ibtidaiyah yang ada di KKM-MI I Kediri - Kuripan Lombok Barat. Madrasah ibtidaiyah sebagai fondasi atau dasar bagi siswa untuk menuju level madrasah berikutnya diharapkan memiliki daya saing, kualitas, dan mental pejuang agar mampu menempatkan posisi sekolahnya sebagai acuan, tujuan, favorit, dan kiblat bagi sekolah-sekolah lain. Siswa-siswa akan termotivasi untuk selalu meningkatkan kemampuannya yang berimbas pada kualiatas yang meningkat. Karena secara definisi motivasi merupakan suatu kekuatan dan suatu keadaan yang kompleks serta kesiapsediaan dalam diri individu untuk bergerak menuju tujuan tertentu baik disadari maupun tidak disadari, Abin Syamsuddin Makmun ( 2012:37). Sehingga madrasah ibtidaiyah bisa bersaing dan mensejajarkan dirinya dengan sekolah-sekolah lain dibawah kemendiknas dalam bidang sains utamanya matematika.

Menurut data, hingga tahun 2017 madrasah ibtidaiyah kabupaten Lombok Barat belum pernah meraih juara olimpiade matematika, baik dari kompetisi OSN maupun KSM. Secara regional pun masih menunjukkan prestasi yang masih jauh dari harapan. Kondisi ini sangat memprihatinkan, karena madrasah sebagai sekolah yang diharapkan mampu mengkolaborasikan pengetahuan agama dan umum sebagai satu kesatuan yang utuh dan saling mendukung, nampak rapuh dan berat sebelah. Ketidakseimbangan antara kemampuan di bidang umum dan agama bisa jadi mendorong para orang tua untuk menyekolahkan anakanaknya ke sekolah-sekolah umum yang lebih favorit. Lambat laun, kondisi ini bisa menggerus keberadaan dan eksistensi madrasah di masa mendatang.

Sementara itu, salah satu acuan bagi para orang tua untuk melihat kualitas suatu sekolah adalah raihan prestasi yang diukir oleh sebuah sekolah. Tidak hanya prestasi di bidang agama, namun juga prestasi bidang umum. Oleh karena itu, pengabdi berupaya melakukan suatu terobosan untuk memecahkan kelangkaan prestasi madrasah dalam kompetisi matematika, melalui pelatihan olimpiade matematika bagi guru-guru matematika di madrasah. Kegiatan ini diharapkan mampu mendorong para guru untuk meningkatkan prestasi siswa-siswanya. Trianto mengatakan bahwa seorang guru harus mampu berimprovisasi dalam segala medan yang dihadapi, termasuk dalam menghadapi siswa yang berkemampuan beragam, materi yang tersebar dalam berbagai sumber, mata pelajaran yang harus dilengkapi dengan sarana dan 
prasarana yang sesuai, serta mampu menyusun kompetensi yang harus dicapai oleh siswa yang dididiknya.

Pelatihan ini diberikan pada guru-guru madrasah ibtidaiyah di KKM-MI I Kuripan Lombok Barat sebagai sampel awal dalam ruang lingkup kecil untuk menjamin efektivitas kegiatan, agar tepat sasaran dan sesuai tujuan. Guru yang telah mendapat pelatihan diharapkan mampu mendampingi siswa-siswanya dalam berlatih untuk mengikuti kompetisi matematika, yang nantinya akan mengharumkan sekolahnya serta menempatkan sekolahnya sebagai sekolah yang diminati banyak orang karena terobosan prestasi dan berbagai inovasi yang dilakukan oleh sekolah tersebut. Sekolah berinovasi biasanya muncul dari adanya keresahan dari pihak-pihak tertentu tentang penyelenggaraan pendidikan, baik masalah relevansi, kualitas, efektivitas, efisiensi, maupun daya tamping sekolah, Wina Sanjaya (2015:318).

KKM-MI I Kediri-Kuripan merupakan gabungan dari 11 madarah ibtidaiyah yang ada di Lombok Barat. Dengan memberikan pelatihan pada guru matematika di KKM-MI I Kediri-Kuripan maka misi dari pelatihan matematika bagi guru madrasah ibtidaiyah bisa menyentuh seluruh madrasah yang ada di KKM-MI I-Kediri-Kuripan. Karena pelatihan ini akan diikuti oleh guru matematika sebagai perwakilan dari setiap madrasah yang ada di KKM-MI I Kediri - Kuripan, dimana setiap madrasah akan mengirimkan wakilnya sebanyak dua orang guru. Ini berarti, meskipun kegiatan terlihat dalam lingkup kecil namun efeknya lebih luas.

Melalui pelatihan olimpiade matematika ini, guru-guru madrasah diharapkan memiliki kecakapan dan pengetahuan yang cukup baik sehingga mampu menjadi pelatih olimpiade matematika di madrasahnya masing-masing. Selain itu, guru-guru yang sudah mendapatkan pelatihan akan saling berbagi informasi tentang model soal, cara, dan teknik penyelesaian soal olimpiade matematika, yang pada akhirnya ukiran prestasi terbaik di masa mendatang. Oleh karena itu, Bahrul dan Suhendra mengatakan bahwa guru akan memiliki tiga komponen literasi matematika berupa komponen proses, komponen konten, dan komponen konteks dari penerapan sehingga mampu menjadi pelatih olimpiade matematika bagi siswa-siswanya.

\section{Metode}

Pelatihan Olimpiade matematika pada Guru Matematika Madrasah Ibtidaiyah Di KKM MI I Kediri Kuripan diselenggarakan 3 tahap yakni:

1. Uji kemampuan awal peserta

Sebelum memasuki sesi materi pelatihan olimpiade matematika, para peserta yakni guruguru madrasah ibtidaiyah di KKM-MI I Kediri Kuripan mengikuti uji kemampuan awal terhadap soal-soal olimpiade matematika tingkat sekolah dasar. Hal ini bertujuan untuk menyegarkan kembali ingatan peserta pada soal-soal olimpiade matematika SD/MI serta untuk meengetahui dan memetakan sejauh mana tingkat pemahaman peserta atau guru dalam memecahkan soal olimpiade.

2. Pelatihan dari narasumber

Pada sesi ini, materi dibawakan oleh dua orang narasumber yang professional di bidang pelatihan matematika khususnya olimpiade matematika. Materi tersaji dalam dua sesi 
dimana setiap sesi berdurasi 2 jam. Pemateri 1 pada sesi pertama membawakan materi pendahuluan dan materi geometri. Materi pendahuluan menggambarkan sejarah olimpiade matematika di Indonesia serta capaian yang diperoleh siswa-siswa tanah air di kanca internasional. Materi geometri yang disajikan pada sesi pertama tentunya sesuai dengan materi yang sudah menjadi materi olimpiade yang diperlombakan baik secara nasional maupun internasional. Pada sesi kedua, pemateri 2 menyajikan maeri aljabar dimana materi ini merupakan materi yang sangat krusial mengingat setiap persoalan yang muncul dalam soal olimpiade salah satunya mengharuskan kemampuan aljabar yang baik untuk mengurai setiap persoalan matematika ke dalam bentuk persamaan matematika (model matematika) agar dapat diselesaikan dengan baik dan benar.

3. Uji kemajuan dari hasil pelatihan

Pada sesi terakhir dari rangkaian pelatihan olimpiade ini adalah uji kemajuan dari hasil pelatihan. Kegiatan ini bertujuan untuk melihat tingkat daya serap peserta pelatihan olimpiade matematika SD/MI terhadap materi yang disajikan.

\section{Hasil dan Pembahasan}

Peserta pada kegiatan " Pelatihan Olimpiade Matematika pada Guru Matematika Madrasah Ibtidayah di KKM-MI I Kediri-Kuripan Lombok barat" adalah guru-guru madrasah ibtidaiyah yang mengajar matematika di kelas , utamanya untuk kelas-kelas atas ( kelas 4, 5, dan 6) dan bejumlah 20 orang.

Narasumber pada kegiatan pelatihan olimpiade matematika ini terdiri atas dua orang, dimana keduanya berprofesi sebagai dosen pada Universitas Islam Negeri Mataram (UIN Mataram). Kedua narasumber tersebut, yakni:

a. Sofyan Mahfudy, M.Pd. sebagai pemateri 1, yang membawakan materi awal berupa sejarah olimpiade, sifat dan karakteristik soal olimpiade SD, materi olimpiade SD (geometri).

b. Fadrik Adi Fahrudin, M.Pd, sebagai pemateri 2, yang membawakan materi serba serbi olimpiade matematika SD, cara menjawab soal olimpiade SD, dan materi olimpiade SD (aljabar).

Dalam pelatihan ini, unsur moderator sangat dibutuhkan untuk menjembatani komunikasi antara narasumber dan peserta dalam sesi diskusi. Hal ini dimaksudkan agar proses diskusi berjalan lebih tertib dan teratur, sehingga setiap pertanyaan yang diberikan oleh peserta mendapat tanggapan atau jawaban yang tepat dari narasumber. Adapun yang bertindak sebagai moderator pada kegiatan ini adalah saudara Muhamad Akrom, S.Pd., yang merupakan salah satu alumni Tadris Matematika, FTK UIN Mataram. Beliau juga merupakan mantan anggota senat mahasiswa FTK UIN Mataram.

Kegiatan pelatihan olimpiade matematika bagi guru madrasah ibtidaiyah dilaksanakan berdasarkan jadwal dan undangan yang diberikan kepada peserta. Kegiatan ini berjalan dengan baik dan lancar sesuai target kegiatan. Kegiatan pelatihan dimulai dengan acara pembukaan yang diikuti oleh peserta, pengabdi, dan ketua Kelompok Kerja Madrasah (KKM) - Madrasah Ibtidaiyah I Kediri - Kuripan Lombok Barat. 
Kegiatan pembukaan diawali dengan kata sambutan dari pengabdi. Pengabdi memberikan gambaran tentang pentingnya pelatihan olimpiade matematika bagi guru-guru madrasah di lingkungan KKM-MI I Kediri Kuripan Lombok Barat. Pengabdi menjelaskan bahwa dengan memberikan pelatihan kepada guru-guru matematika madarasah ibtidayah diharapkan guruguru mampu melatih siswa-siswanya sendiri di sekolah masing-masing terkait dengan persiapan siswa dalam kompetisi olimpiade matematika yang diselenggarakan secara kontinu setiap tahun oleh pemerintah. Selain itu, pengabdi juga sekedar mengingatkan peserta yang hadir bahwa Institut Agama Islam Negeri ( IAIN ) Mataram sudah resmi berubah status menjadi sebuah universitas yakni Universitas Islam Negeri Mataram ( UIN Mataram). Hal ini bisa membawa angin segar bagi kalangan akademisi di UIN Mataram dan bisa dimungkinkan bahwa kegiatan pelatihan serupa atau kegiatan pelatihan dalam peningkatan kapasitas guru bisa diselenggarakan di tempat dan peserta yang sama atau dalam ruang yang lebih luas di masa mendatang. Pernyataan pengabdi ini disambut tepuk meriah dan senang oleh para peserta.

Setelah pengabdi menyampaikan sepatah kata, dilanjutkan oleh ketua KKM-MI I KediriKuripan, Ibu Sufiatun Shofwan, M.Pd.I. menyampaikan beberapa hal dan sekaligus membuka acara kegiatan pelatihan olimpiade matematika secara resmi. Sebagai ketua KKM-MI KediriKuripan, beliau berharap bahwa kegiatan ini bisa membawa angin segar bagi guru-guru MI dalam membina siswa-siswanya untuk berkompetisi dalam bidang matematika. Dengan kegiatan ini, guru-guru dapat menambah pengetahuan dan wawasan terhadap materi-materi serta teknik menjawab soal-soal olimpiade matematika SD. Ibu Sufiatun mengatakan bahwa, guru-guru MI di KKM-MI I Kediri Kuripan sangat membutuhkan kegiatan pelatihan olimpiade matematika ini. Guru-guru MI masih kurang pengalaman dalam hal membina olimpiade matematika serta sampai saat ini belum mampu menghadirkan siswa-siswa madrasah ibtidaiyah yang berprestasi dalam bidang olimpiade matematika. Selama ini siswa dibina dengan apa adanya tanpa dibekali dengan sistem dan teknik pembinaan yang memadai. Terlebih lagi, pembinaan olimpiade tidak terencana atau terjadwal dengan baik. Pembinaan biasanya dilakukan beberapa kali saja menjelang kompetisi diselenggarakan.

Ibu Sufiatun mengungkapkan pula bahwa kondisi guru-guru matematika di KKM MI I Kediri Kuripan kurang dari sentuhan pelatihan profesional dalam rangka peningkatan dan penguatan kemampuan guru dalam akademik dan manajemen pendidikan. Oleh karena itu, beliau berharap guru-guru yang mengikuti kegiatan ini benar-benar disiplin dan sungguhsungguh aktif mengikuti pelatihan olimpiade matematika dari awal hingga akhir pelatihan. Selain itu, beliau berharap agar kegiatan serupa dapat dilakukan kembali di masa yang akan dating, tidak berhenti sekali dan hanya saat ini. Dengan kegiatan berkesinambungan akan memberikan pengaruh serta perubahan yang baik dan efektif terhadap kemampuan guru-guru madrasah ibtidaiyah. Kegiatan ini pula bisa menjadi ajang silaturahmi antara guru-guru matematika madrasah ibtidaiyah dengan dosen matematika UIN Mataram, dan menjadi sarana diskusi dan sharing informasi terkait bahan atau materi terkini dari olimpiade matematika SD.

Pada kesempatan itu pula, sebagai ketua KKM-MI I Kediri Kuripan, beliau mengucapkan terimakasih kepada pengabdi atas pilihannya kepada guru-guru matematika MI di KKM-MI I Kediri Kuripan sebagai sasaran dan subjek pengabdiannya. Setelah dibuka dengan resmi oleh 
ibu Sufiatun Shofwan, M.Pd.I, kegiatan pelatihan dilanjutkan dengan pre test. Kegiatan pre test dimaksudkan untuk mengetahui kemampuan guru-guru matematika madrasah ibtidaiyah di lingkungan KKM-MI I Kediri Kuripan dalam memahami dan memecahkan problem atau soal olimpiade matematika SD. Pre test ini berjumlah 10 soal dan terdiri atas soal-soal tentang aljabar, geometri, statistika, dan kapita selekta. Soal-soal pre test dikerjakan oleh peserta pelatihan selama 60 menit.

Selama pre test berlangsung, terkadang peserta saling berkomunikasi untuk mendiskusikan soal, namun karena ini tes atau ujian individual, maka pihak panitia memberikan peringatan dengan tegas dan sopan, sehingga dengan taat seluruh peserta mengerjakan soal dengan mandiri. Hasil pre test guru-guru matematika peserta pelatihan olimpiade matematika SD sangat memprihatinkan. Hal ini beralasan karena dari sepuluh soal yang ada, hanya 2 soal yang dijawab tuntas oleh 6 orang peserta. Sedangkan 9 orang yang lain hanya mampu menjawab 1 soal, sisanya tidak satupun mampu menjawab soal. Ini memberikan gambaran bahwa kemampuan guru-guru matematika madrasah ibtidaiyah di KKM-MI I Kediri-Kuripan sangat rendah dalam menyelesaikan atau memecahkan soal olimpiade matematika SD. Artinya guru-guru selaku peserta pelatihan olimpiade matematika SD masih sulit menganalisa soal-soal olimpiade matematika SD.

Pada pelatihan olimpiade matematika ini, narasumber yang pertama adalah Bapak Sofyan Mahfudy, M.Pd. Beliau membawakan materi geometri yang merupakan materi dominan di dalam olimpiade matematika SD. Selain itu, beliau juga memberikan gambaran tentang kiat-kiat dan strategi dalam menghadapi kompetisi olimpiade matematika.

Bapak Sofyan Mahfudy mengawali materinya dengan menjelaskan kepada peserta bahwa olimpiade matematika adalah kompetisi spesial yang diikuti oleh anak-anak yang spesial. Karena soal-soal yang dihadapi di dalam olimpiade matematika adalah juga soal-soal yang spesial. Oleh karena itu, maka siswa sebagai peserta olimpiade matematika harus dipersiapkan dengan matang dan sungguh-sungguh. Siswa harus didorong untuk rajin dan tekun melatih kemampuannya dalam memecahkan soal-soal olimpiade. Dengan banyak berlatih dan mengasah kemampuan, seseorang akan mampu menjawab soal olimpiade matematika dengan tepat dan kreatif.

Dalam membawakan materi geometri, Bapak Sofyan Mahfudy kerap kali mengundang gelak tawa dan tepuk tangan. Karena kadang peserta diberi soal sederhana untuk dijawab, namun tak satupun mampu menjawabnya. Tapi setelah diberi penyelesaian oleh beliau, peserta rata-rata tidak menyangka model penyelesaiannya sesederhana itu. Memang soal olimpiade membutuhkan kreativitas dan ide cemerlang dalam menentukan solusi tepat dan benar.

Bapak Sofyan Mahfudy membawakan materi dengan metode diskusi dan tanya jawab. Sehingga ketika materi berlangsung, kadang ada peserta yang bertanya sehingga materi dihentikan sementara. Pertanyaan peserta terkadang sangat mendasar dan sangat sederhana. Misalnya peserta yang bernama Bapak Habibi, S.Pd. bertanya," kenapa sudut A dan sudut B pada soal di papan nilainya sama, pak?". Pertanyaan ini mengindikasikan bahwa peserta tersebut sama sekali tidak mengetahui atau lupa sama sekali dengan konsep sudut berseberangan. 
Materi geometri ditutup dengan soal terakhir tentang luas daerah yang diarsir. Meskipun tak satupun peserta mampu menjawab secara mandiri, namun sudah mampu memberikan beberapa informasi yang benar dalam menjawab soal tersebut. Ini berarti bahwa peserta telah memiliki beberapa pengetahuan yang sedikit membantu dalam mengurai jawaban sampai kepada kondisi jawaban yang tepat. Materi kedua dilaksanakan setelah istrahat dan makan. Materi kedua dibawakan oleh Bapak Fadrik Adi Fahrudin, M.Pd. Beliau membawakan materi aljabar yang merupakan materi sangat mendasar dalam operasi bilangan. Sehingga materi ini cukup besar mempengaruhi materi-materi lain.

Bapak Fadrik mengawali materi dengan cukup menarik, dimana semua peserta diajak menonton film matematika berdurasi 10 menit. Film ini berkisah tentang anak yang kurang paham dengan matematika, tapi lingkungan tidak memberikan peluang kepada anak ini untuk melakukan perubahan terhadap ketidakmampuannya. Justru ia selalu disudutkan oleh orang tuanya dengan membanding-bandingkannya dengan saudaranya yang pintar matematika. Padahal, sebagai orang tua yang baik seharusnya memberikan dukungan dan dan pembelajaran serta nasehat dengan metode yang tepat, agar anak tidak merasa dikekang dan tidak terbebani. Gurupun harusnya mencoba memberikan pelajaran dengan pendekatan yang terbaik dan cocok, serta selalu membesarkan hati dan semangat anak meskipun saat itu belum terlalu paham. Jika lingkungan memberikan dukungan yang baik, besar peluang anak tersebut bisa bangkit dari keterpurukannya. Hal ini juga dibenarkan oleh seluruh peserta pelatihan, mereka memberi tanggapan terhadap film ini bahwa anak yang kurang paham bukannya dijatuhkan mentalnya, melainkan didorong semangatnya untuk bangkit secara bertahap untuk belajar dengan giat. Siswa diajar dengan kasih saying bukan penuhi oleh tekanan mental. Mayoritas dari peserta pelatihan sedih dan mata berkaca-kaca ketika menyaksikan film ini.

Pada kesempatan ini, Bapak Fadrik mencoba untuk saling mengingatkan bagaimana cara yang tepat untuk menghadapi anak dengan kemampuan matematika yang kurang atau rendah. Menurut beliau, anak akan hebat dan tumbuh menjadi anak yang luar biasa jika kita bisa menahan diri dari emosi sesaat ketika sedang mengajar putra putri kita. Emosi sesaat hasilnya bagus hanya sesaat namun efek buruk terhadap anak bisa berkepanjangan.

Oleh karena matematika sudah memiliki kesan yang horror bagi siswa, maka sebagai guru yang profesional sebaiknya memberikan pembelajaran matematika kepada siswa dengan metode dan pendekatan yang terbaik. Sehingga anak-anak mudah memahami dan tertarik terhadap matematika. Terlebih lagi dengan materi olimpiade matematika, anak akan sulit dan bisa saja bosan jika guru tidak menemukan cara dan metode yang baik dalam memecahkan soal matematika. Selain itu, dibutuhkan kesabaran dalam membimbing anak didik agar anak didik merasa nyaman dan mudah diarahkan ketika kita sebagai guru yang dipercaya oleh sekolah membimbing anak-anak ini.

Materi aljabar yang dibawakan oleh Bapak Fadrik mendapat perhatian yang sungguhsungguh dari seluruh peserta. Hal ini bisa terlihat dari antusias peserta pelatihan dalam memberikan pertanyaan kepada Bapak Fadrik, baik pertanyaan mengenai cara mendapatkan ide maupun operasi aljabar yang dilakukan pada setiap langkah penyelesaian soal olimpiade matematika. Sesekali peserta mencoba memberikan idenya terhadap soal yang belum tuntas dikerjakan. 
Bapak Fadrik menutup materi dengan pernyataan beliau bahwa untuk berhasil dalam olimpiade matematika ini, siswa harus banyak berlatih dan guru tidak boleh menyerah dalam membimbing mereka. Dengan kerja keras secara disiplin dan bertanggung jawab serta doa, bukan sesuatu yang mustahil anak akan mencapa prestasi yang gemilang. Pernyataan tersebut disambut dengan tepuk tangan yang gemuruh dari para peserta.

Post test pada pelatihan ini dilakukan setelah Bapak Fadrik mengakhiri materinya. Post test ini dilakukan untuk mengetahui sejauh mana efek pelatihan olimpiade matematika SD terhadap peserta pelatihan. Dan ternyata, post test menunjukkan angka sedikit lebih baik yakni ada 15 orang yang mampu menjawab 2 soal dengan benar, dan ada 2 peserta yang mampu menjawab 3 nomor soal dengan benar. Sedangkan yang lain, ada yang hanya mampu menjawab 1 nomor dan ada juga setengah nomor. Setelah berakhirnya post test, pengabdi menutup acara dengan mengucapkan terimakasih atas partisipasi peserta dalam pelatihan olimpiade serta panitia dan Ibu Sufiatun Shofwan, M.Pd.I. yang telah memberikan dukungan yang cukup besar terhadap kelancaran dan kesuksesan kegiatan.

\section{Kesimpulan}

Kesimpulan pelaksanaan kegiatan pengabdian ini adalah sebagai berikut:

a. Faktor-faktor kesulitan guru-guru MI pada KKM-MI I Kediri-Kuripan dalam memahami soalsoal olimpiade matematika adalah guru-guru tidak terbiasa mengerjakan soal-soal olimpiade matematika, guru-guru jarang mempelajari materi-materi olimpiade matematika baik secara konsep maupun prinsip, serta jarang mengikuti pelatihan olimpiade matematika sebagai bekal membimbing anak didiknya dengan baik.

b. Pelatihan Olimpiade Matematika tingkat SD/MI berdampak positif terhadap kemampuan guru-guru matematika pada KKM-MI I Kediri - Kuripan Lombok Barat. Hal ini sangat masuk akal karena nilai rata-rata post test -nilai rata-rata pre test lebih besar dari nol.

Sebagai pelaksana pelatihan olimpiade matematika, pengabdi berharap agar kegiatan pelatihan ini dapat diselenggarakan tidak hanya sekali, namun dapat dilaksanakan secara berkelanjutan, dengan harapan guru-guru bisa memiliki bekal yang cukup memadai dalam membina anak didiknya untuk berkompetisi dalam olimpiade matematika, sehingga memperoleh predikat juara.

\section{REFERENSI}

Fattah Nanang. 2004. Konsep Manajemen Berbasis Sekolah (MBS) dan Dewan Sekolah. Bandung: CV Bani Quraisy

Hayat Bahrul, Yusuf Suhendra. 2010. Mutu Pendidikan. Jakarta: Sinar Grafika Offset

https://id.wikipedia.org/wiki/Olimpiade_Matematika_Internasional diakses pada tanggal 28 Agustus 2017 Schmoker Mike. 2012. Menjadi Guru Yang Efektif. Jakarta: Erlangga

Sanjaya Wina. 2015. Kurikulum Pembelajaran. Jakarta: Prenada Media Group

S.S. Wibowo. 2015. Kumpulan Soal dan Pembahasan Olimpiade Matematika SD(jilid 1). Bandung: Yrama Widya S.S. Wibowo. 2015. Kumpulan Soal dan Pembahasan Olimpiade Matematika SD (jilid 2). Bandung: Yrama Widya Syamsuddin Abin. 2012. Psikologi Kependidikan. Bandung: PT Remaja Rosdakarya Tirtahardja Umar, La Sulo. 2005. Pengantar Pendidikan. Jakarta: PT Rineka Cipta

Trianto. 2013. Konsep Desain Pengembangan Pembelajaran Tematik. Jakarta: Kencana Prenada Media Group 